
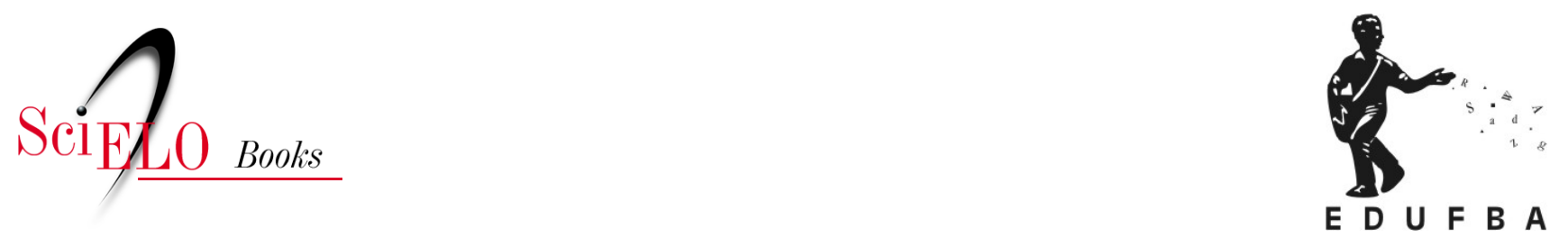

\title{
Reflexões \\ Informações acessíveis e a telinha do avião
}

\author{
Nelson De Luca Pretto
}

PRETTO, N.D.L. Informações acessíveis e a telinha do avião. In: Educações, culturas e hackers: escritos e reflexões [online]. Salvador: EDUFBA, 2017, pp. 167-170. ISBN: 978-85-232-2019-8. https://doi.org/10.7476/9788523220198.0043.

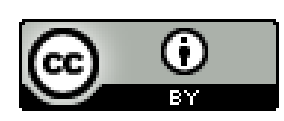

All the contents of this work, except where otherwise noted, is licensed under a Creative Commons Attribution $\underline{4.0 \text { International license. }}$

Todo o conteúdo deste trabalho, exceto quando houver ressalva, é publicado sob a licença Creative Commons Atribição 4.0.

Todo el contenido de esta obra, excepto donde se indique lo contrario, está bajo licencia de la licencia Creative Commons Reconocimento 4.0. 
Mais do que preocupante, isso é grave. A manifestação dos colegas de Pernambuco também foi explícita nesse sentido, já que o decreto não indicou se "o prédio do MCT BA, fazendo parte desta história como marco arquitetônico da museologia científica [seria] preservado exclusivamente para suas atividades de educação e popularização da ciência”, como todos defendemos.

Este texto, antes pensado exclusivamente para ser dirigido aos três candidatos à reitoria da UNEB, agora tem entre os seus destinatários os Exmos. Governador da Bahia e Secretário da SECTI que precisam, urgente e publicamente, assumir um compromisso com a história, a ciência e a tecnologia em nosso Estado.

Por favor, não matem a nossa história! Salvemos o Museu de Ciência e Tecnologia da Boca do Rio.

Publicado no jornal A Tarde, Salvador, em 17 de setembro de 2013.

\section{Informações acessíveis e a telinha do avião}

Embarco tranquilamente no elegante avião Embraer 190, num voo da Azul de Salvador para Campinas, São Paulo, aeroporto de Viracopos. De lá, ainda seguirei para Navegantes, em Santa Catarina. É uma bonita manhã de sol e o avião decola tranquilamente. Curioso, coloco logo na telinha o mapa de voo, pois, entre uma página e outra do livro que leio Hacking: digital media and society series, de Tim Jordan - dou uma espiada na velocidade, altitude e a rota que faremos nesta manhã de quarta feira. 
Assim que decolamos, muitas nuvens precisam ser atravessadas e passamos imediatamente a voar por cima delas. Olhando o mapinha na tela à minha frente, verifico o nome da cidade de partida: Teresina, no Piauí. O avião correndo e subindo, a velocidade aumentando, indo até $671 \mathrm{~km} / \mathrm{h}$ e a aeronave à minha frente, na telinha, faz uma curva, meio que igualzinha à que faço dentro do Embraer 190. No mapa, começamos a nos deslocar para Floriano, depois Ribeiro Gonçalves e, em breve, o Tocantins. Justo o Tocantins, objeto do estudo de uma orientanda nossa que ontem apresentou sua tese sobre e-jovens e seus grupos de rock em Palmas, capital do estado. Momentaneamente, pensei que estava para lá me dirigindo para entender a cibercultura in loco!

$\mathrm{O}$ aviãozinho da tela para. O nosso não...

À medida que continuamos a viagem e deixamos para trás o nosso aviãozinho da tela, lá no norte do país, minha memória me leva para longe do livro sobre hackers e crackers e começo a olhar para fora, pensando no voo da falecida Varig que saiu num final da tarde de Brasília em direção, se não me falha a memória, a Belém. Era um dia de jogo da copa do mundo e torcíamos pela seleção brasileira, sem nem mesmo mencionar essa tal de Fifa, que hoje manda em tudo e em todos. Pois, nesse dia, um passageiro frequente, sentado na janela do lado direito da aeronave, tentava desfrutar do infinito da paisagem externa, onde a temperatura é sempre em torno de $40^{\circ} \mathrm{C}$ negativos. Relaxado, imagino, estaria ele pensando na vida e, para sua surpresa, na sua mirada distante, via um lindo pôr do sol. A beleza do fenômeno não o deixou tranquilo, pois, se para o norte se dirigia, jamais poderia estar vendo um por do sol, se sentado estava do lado direito da aeronave. Mesmo sendo um tempo em que o serviço de bordo era generoso e podíamos bebericar umas coisinhas, o nosso passageiro pareceu não estar muito convencido do que via e chamou a aeromoça para alertá-la de que algo parecia estar errado. E, por exclusão, imaginava que não era o sol! Nosso conhecimento empírico dizia que aquele avião não poderia estar indo na direção correta...

Ninguém o ouviu. Nada foi feito e o final dessa história é trágica e não vou buscar na internet número de mortos, tempo que os sobreviventes ficaram na selva e os tantos outros desdobramentos decorrentes do 
erro de rota pois, para isso, é melhor não acionar nossa memória, nem os mecanismos de busca.

Justo isso tudo me veio à cabeça ao ver a telinha com a imagem do avião indo a sentido contrário ao nosso.

Por medo, não olho para o lado de fora quando estou nos voos. Sou um screenager, como diz Douglas Rushkoff, vivo com as telas por todos os cantos e lados, mas tinha certeza de que havia uma inconsistência nas informações apresentadas, mesmo sem ser o momento de um pôr do sol. Em função de minha leitura, pensei logo em crackers bandidos e malvados às vésperas da Copa! Pensei na tal interferência dos celulares nos computadores de bordo... mas continuava tenso.

Como a altitude continuava a indicar claramente um movimento de subida e na expectativa de que o problema seria resolvido ou pelo menos explicado, gentilmente chamo a aeromoça líder no voo Azul 4299 e digo: senhorita, o sistema do mapa de voo deve estar com problema, imagino que não seja o mesmo do piloto, mas, por segurança, pode avisá-lo do fato, por favor? A reação foi de surpresa e a sua expressão era de que o meu pedido não seria atendido. Esperei um pouco. Ela sentadinha ali na minha frente, o fone de comunicação ao seu lado e... nenhum movimento. Ela se desloca para o fundo, para junto dos demais da tripulação. Como precisava ir ao banheiro - não, não, eu não estava nervoso, estava supertranquilo, fui só porque bebi um pouco mais de água do que devia! -, mais uma vez, perguntei: avisou ao comandante? Sim, fique tranquilo, o sistema das tvs não é o mesmo da cabine, responde ela, que se diz também piloto! Pensei comigo, como se tivesse no tal voo da Varig: não, meu senhor, aquela bola amarela lá ao fundo que o senhor está vendo não é o sol se pondo...

Insisti que necessário se fazia uma explicação para todos, podia ter mais gente preocupada, já que nós, simples mortais (ooppss, passageiros), estávamos vendo uma coisa na tela e outra acontecia ou pele menos deveria acontecer!

Penso que, finalmente, ela comunicou ao comandante que, sem mencionar o problema, apenas disse que estávamos na rota 40 (acho que foi isso), sobrevoando Vitória do Espírito Santo (uuaauuu) e que depois 
iríamos para Campinas. Levantei os olhos e o aviãozinho da tela estava ali, parado em Teresina. Menos mal, pelo menos ele tinha parado e nós aqui continuávamos voando.

Chegamos tranquilo aqui no sul, justamente como previsto e não visto na telinha, em Campinas. O pouso foi bom, o sol brilhava e a temperatura, na casa dos 22 graus.

Disso tudo, fico aqui no aeroporto esperando o próximo voo e pensando como é difícil se compreender que a informação é algo muito precioso e que tem que estar aberta e disponível para todos, o tempo todo. Informação tem que circular, ser acessível para possibilitar que cada um, especialista ou não, possa, com os dados em mãos - e em máquina avaliá-las em profundidade, ou simplesmente verificar a sua consistência. Afinal, norte é norte e sul é sul. O resto é telinha de avião!

\section{O mundo está cada vez mais aberto!}

Uma boa notícia nos chega da Universidade Estadual de Campinas (Unicamp) que lançou, na semana passada, um portal com vídeos, animações e mais de mil imagens de acesso gratuito. Tudo licenciado em Creative Commons, o que possibilita que o usuário pode usar livremente esses produtos, inclusive remixando-os, ou seja, misturando tudo para produzir mais imagens, animações e vídeos. O material está disponível na internet ${ }^{54} \mathrm{e}$ lá, além do que já está pronto e produzido pelos professores e pesquisadores da Unicamp, existe uma ferramenta aberta - em software livre - que possibilita que se criem mais materiais, esta também livre.

\footnotetext{
${ }^{54}$ Disponível em: <www.ggte.unicamp.br/e-unicamp >.
} 